Corps et culture

Numéro 3 | 1998

Sport et lien social

\title{
L'écriture du corps
}

\section{Mahmoud Miliani}

\section{(2) OpenEdition}

Journals

Édition électronique

URL : http://journals.openedition.org/corpsetculture/1014

DOI : 10.4000/corpsetculture.1014

ISSN : $1777-5337$

\section{Éditeur}

Association Corps et Culture

Édition imprimée

Date de publication : 1 juin 1998

ISSN : 1268-5631

Référence électronique

Mahmoud Miliani, "L'écriture du corps », Corps et culture [En ligne], Numéro 3 | 1998, mis en ligne le 24 septembre 2007, consulté le 24 septembre 2020. URL : http://journals.openedition.org/ corpsetculture/1014; DOI : https://doi.org/10.4000/corpsetculture.1014

Ce document a été généré automatiquement le 24 septembre 2020.

(c) tous droits réservés 


\section{L'écriture du corps}

Mahmoud Miliani 